REVIEW

\title{
Thrombolysis: past, present, and future
}

D Gray

Postgrad Med J 2006;82:372-375. doi: 10.1136/pgmj.2005.033266

Management of myocardial infarction evolved because of understanding of underlying disease processes and clinical trials of "chemical" and "mechanical" clot dissolution that reduced in-hospital mortality. Meta-analysis comparing these treatment strategies marginally favours angioplasty. Current European Society of Cardiology guidelines propose primary angioplasty as the preferred therapeutic option but few units in the UK can offer angioplasty on demand as a designated "heart attack centre". Thrombolysis will continue as it is widely available and training needs and costs less than angioplasty. Community thrombolysis should be made available for those patients who do not wish for such aggressive intervention or as a prelude to transfer time to a heart attack centre distant from a triage hospital.

Correspondence to: Dr D Gray, University Hospital, Nottingham NG7 2UH, UK; d.gray@ nottingham.ac.uk

Submitted 9 February 2005 Accepted 22 November 2005
A cute myocardial infarction remains one of the most common causes of death in the western world. Mortality and morbidity are the result of ischaemia, causing pump failure, ventricular arrhythmia, and cardiac rupture. Mortality was reduced after the opening of coronary care units (CCUs) in the late 1960s to monitor for and treat cardiac arrhythmia, particularly ventricular fibrillation, and training of ambulance crew in first basic, and later advanced, cardiopulmonary resuscitation. Pharmacological intervention was hindered by imperfect understanding of the pathophysiology of coronary disease as at that time thrombotic occlusion of a coronary artery at a site of atherosclerotic plaque was considered to be a consequence rather than a cause of infarction ${ }^{1}$ until pioneering work by Falk ${ }^{2}$ and by Davies and Thomas $^{3}$ in the 1980s. Improved knowledge of the coagulation and fibrinolytic systems and their contribution to the acute coronary occlusive process heralded the era of thrombolysis.

\section{A BRIEF HISTORY OF THROMBOLYSIS}

That some strains of streptococci could induce fibrinolysis in human plasma clots had been known for decades. ${ }^{4}$ The results of early trials in acute myocardial infarction showing a significant reduction in mortality were ignored for over 30 years because of uncertainty about the aetiology of the infarction process until both intra-arterial $^{5}$ and intravenous streptokinase $(\mathrm{SK})^{6}$ induced rapid recanalisation of occluded vessels, preserved left ventricular function, ${ }^{7}$ and decreased mortality.
A series of multicentre, international megatrials investigated the clinical relevance of thrombolysis-SK ${ }^{8}$ and APSAC, a variant of $\mathrm{SK}^{10}$ reduced early mortality by $23 \%-50 \%$ with minimal risk of bleeding and stroke if given within six hours or so of the acute event, the so called thrombolytic window. Aspirin reduced mortality at least as well as SK but the combination proved even more effective. ${ }^{9}$ These clinical trials changed medical practice as thrombolysis was rapidly adopted as the gold standard (table 1).

Genetic engineering produced a crop of new agents. First came tissue plasminogen activator or t-PA that improved coronary patency more than $\mathrm{SK}^{11}$ and a larger first dose (or front loading) of t-PA produced more rapid re-perfusion, ${ }^{12}$ followed by Reteplase ${ }^{13}$ and Teneceteplase, ${ }^{14}$ both at least as effective as existing agents, but with simpler dosing regimens.

\section{POTENTIAL PROBLEMS WITH THROMBOLYTIC DRUGS}

Thrombolytic drugs are remarkably well tolerated, with nausea, vomiting, and bleeding from injection sites the most common problems. Allergic reactions may occur with SK but all agents can cause hypotension, reperfusion arrhythmias, and intracerebral haemorrhage.

Contraindications generally relate to risk of bleeding and in the case of streptokinase, allergy, or lack of efficacy due to persistent antistreptococcal antibodies.

\section{CONVERTING TRIAL SUCCESS INTO ROUTINE CLINICAL PRACTICE}

Thrombolysis was introduced fairly quickly into routine hospital practice soon after the publication of clinical trials in 1988, with most CCUs adopting a treatment time window of up to six hours after the onset of symptoms, based on ISIS-2, and later up to 14 hours in line with ASSET findings.

At this time, all patients tended to be examined and diagnosed either in the CCU or in the emergency department by a junior doctor, who prescribed a thrombolytic for administration by a nurse. Systems were not efficient and a door to needle time in excess of an hour was not unusual.

After a meta-analysis of published studies, ${ }^{16}$ it became clear that the sooner thrombolysis was given after the onset of chest pain, the greater the survival benefit-the golden hour (later lengthened to about three hours ${ }^{17}$ ) identified the period in which greatest benefit derived. The concept of fairly leisurely treatment on the basis of the thrombolytic window had to be aban- 
Table 1 Selected landmark clinical trials in thrombolysis

\begin{tabular}{|c|c|c|c|}
\hline Clinical trial & Thrombolytic & Trial design and treatment regimen & Main findings \\
\hline GISSI- 1 & $\mathrm{SK}^{8}$ & $\begin{array}{l}\text { Randomised, un-blinded. Conventional treatment }+/- \text { SK } \\
1.5 \mathrm{M} \text { units IV. Concomitant therapy according to normal } \\
\text { practice. }\end{array}$ & $\begin{array}{l}21 \text { day mortality SK } 10.7 \% \text { v controls } 13 \% \text {. At one year, } \\
\text { mortality SK } 17.2 \% \text { v } 19 \% \text { controls. }\end{array}$ \\
\hline AIMS & APSAC $^{10}$ & $\begin{array}{l}\text { Randomised, double blind, placebo controlled. APSAC } \\
300 \text { units IV bolus over } 5 \text { minutes within } 6 \text { hours of symptom } \\
\text { onset; or placebo. Concomitant therapy heparin IV and } \\
\text { other medication according to normal practice. } \beta \text { blocker on } \\
\text { hospital discharge. }\end{array}$ & $\begin{array}{l}\text { Premature termination of trial as } 47 \% \text { reduction in } 30 \text { day } \\
\text { mortality with anistreplase. }\end{array}$ \\
\hline ASSET & $t-P A^{12}$ & $\begin{array}{l}\text { Randomised, double blind, placebo controlled. t-PA } 10 \mathrm{mg} \\
\text { bolus within } 5 \text { hours of symptom onset, followed by infusion } \\
\text { of } 50 \mathrm{mg} / \mathrm{h} \text { for first hour and } 20 \mathrm{mg} / \mathrm{h} \text { for next } 2 \text { hours; or } \\
\text { placebo. Concomitant therapy heparin bolus and infusion } \\
\text { for } 21 \text { hours. Anticoagulation, aspirin, and other antiplatelet } \\
\text { drugs not permitted. } \beta \text { blockers permitted on hospital } \\
\text { discharge. }\end{array}$ & $\begin{array}{l}30 \text { day mortality t-PA } 7.2 \% \text { v } 9.8 \% \text { placebo. } 6 \text { month } \\
\text { mortality t-PA } 10.4 \% \vee 13.1 \% \text { placebo. }\end{array}$ \\
\hline ISIS-2 & $\mathrm{SK}+\mathrm{ASA}^{9}$ & $\begin{array}{l}\text { Randomised, double blind, placebo controlled. } \\
\text { Streptokinase } 1.5 \mathrm{M} \text { units over } 1 \text { hour, and/or aspirin } \\
162.5 \mathrm{mg} / \text { day orally for } 1 \text { month; or placebo. Concomitant } \\
\text { therapy according to normal practice. }\end{array}$ & $\begin{array}{l}35 \text { day vascular mortality SK } 9.2 \% \text { v } 12 \% \text { placebo; Aspirin } \\
9.4 \% \text { v } 11.8 \% \text { placebo; SK plus aspirin } 8 \% \text { v } 13.2 \% \\
\text { placebo. }\end{array}$ \\
\hline GUSTO-I & $\mathrm{SK}+/-\mathrm{Tpa}^{11}$ & $\begin{array}{l}\text { Randomised. SK } 1.5 \mathrm{M} \text { units over } 1 \text { hour plus SC heparin } \\
12500 \text { units twice daily; or SK } 1.5 \mathrm{M} \text { units over } 1 \text { hour plus } \\
\text { IV heparin bolus } 5000 \text { units followed by } 1000-1200 \text { units/ } \\
\text { hr adjusted to APTT of } 60-85 \text { seconds; or accelerated t-PA } \\
\text { as } 15 \mathrm{mg} \text { bolus then } 0.75 \mathrm{mg} / \mathrm{kg} \text { up to } 50 \mathrm{mg} \text { over } \\
30 \text { minutes and } 0.5 \mathrm{mg} / \mathrm{kg} \text { up to } 35 \mathrm{mg} \text { over next } \\
60 \text { minutes with IV heparin as above; or t-PA } 1 \mathrm{mg} / \mathrm{kg} \text { over } \\
1 \text { hour up to } 90 \mathrm{mg} \text { plus SK } 1.5 \mathrm{M} \text { units over } 1 \text { hour given } \\
\text { simultaneously and IV heparin as above. Concomitant } \\
\text { therapy aspirin } 160-325 \mathrm{mg} \text { daily, Atenolol } 5 \mathrm{mg} \text { IV then } \\
\text { oral } 50-100 \mathrm{mg} \text { daily. Other treatment according to normal } \\
\text { practice. }\end{array}$ & $\begin{array}{l}30 \text { day mortality SK plus SC heparin } 7.2 \% \text { v } 7.4 \% \text { SK plus IV } \\
\text { heparin; t-PA plus IV heparin } 6.3 \% \text { v } 7 \% \text { t-PA plus SK plus IV } \\
\text { heparin. }\end{array}$ \\
\hline INJECT & $r-\mathrm{PA} v \mathrm{SK}^{13}$ & $\begin{array}{l}\text { Randomised, double blind. SK } 1.5 \mathrm{M} \text { units over } 1 \text { hour, or r- } \\
\text { PA } 10 \mathrm{mg} \text { double bolus } 30 \text { minutes apart. Concomitant } \\
\text { aspirin and heparin. }\end{array}$ & 35 day mortality r-PA 9\% v 9.5\% SK. \\
\hline ASSENT-2 & $n-P A$ vs $t-P A^{14}$ & $\begin{array}{l}\text { Randomised, double blind. n-PA } 30-50 \mathrm{mg} \text { according to } \\
\text { bodyweight over } 5-10 \text { seconds, or t-PA } 15 \mathrm{mg} \text { bolus } \\
\text { followed by } 0.75 \mathrm{mg} / \mathrm{kg} \text { up to } 50 \mathrm{mg} \text { infused over } \\
30 \text { minutes then } 0.5 \mathrm{mg} / \mathrm{kg} \text { up to } 35 \mathrm{mg} \text { infused over } \\
1 \text { hour; or placebo. Concomitant aspirin and heparin. }\end{array}$ & 30 day mortality n-PA $6.18 \%$ v $6.15 \%$ t-PA. \\
\hline GREAT & Anistreplase $^{15}$ & $\begin{array}{l}\text { Randomised, double blind. Anistreplase } 30 \text { units IV over } \\
5 \text { minutes at home or on arrival in hospital. Patients } \\
\text { receiving placebo at home given anistreplase in hospital. } \\
\text { Concomitant therapy according to normal practice. }\end{array}$ & $\begin{array}{l}1 \text { year mortality } 10.4 \% \text { community treated } v 21.6 \% \\
\text { thrombolysed in hospital. Average "time to thrombolysis" } \\
\text { reduced from } 240 \text { minutes in hospital to } 101 \text { minutess in } \\
\text { community. accompanied by significant reduction in } \\
\text { hospital and one year mortality. }\end{array}$ \\
\hline \multicolumn{4}{|c|}{$\begin{array}{l}\text { SK, streptokinase (non-proprietary and Streptase); t-PA, alteplase (Actilyse); r-PA, reteplase (Rapilysin); n-PA, tenecteplase (Metalyse); APSAC (anisoylated } \\
\text { plasminogen streptokinase activator complex), anistreplase-no longer available in the UK. GISSI-1, Gruppo ltaliano per lo Studio della Streptchinasi nell'Infarto } \\
\text { miocardico. AIMS, APSAC intervention mortality study. ASSET, Anglo-Scandinavian study of early thrombolysis. ISIS-2, second international study of infarct } \\
\text { survival. GUSTO-1, global utilisation of streptokinase and t-PA for occluded coronary arteries-1. INJECT, international joint efficacy comparison of thrombolytics. } \\
\text { ASSENT-2, assessment of the safety and efficacy of a new thrombolytic-2. GREAT, Grampian Region early anistreplase trial. }\end{array}$} \\
\hline
\end{tabular}

doned in favour of rapid appraisal, speedier diagnosis, and prompt delivery of thrombolysis.

\section{SYSTEMS RE-DESIGN}

The National Service Framework for Coronary Heart Disease ${ }^{18}$ provided a stimulus to rapid diagnosis and management of acute infarction, setting a target door to needle time of 30 minutes and later 20 minutes. Re-thinking of clinical roles because of pressure on junior doctors' time and workload encouraged many hospitals to expand the role of the experienced CCU nurse and nurse initiated, protocol driven thrombolysis was introduced. Nationally, $76 \%$ of units meet the 30 minutes criterion. ${ }^{19}$

\section{ADVANTAGES AND DISADVANTAGES OF INDIVIDUAL THROMBOLYTICS}

All thrombolytic agents are of proved efficacy, but convenience and simplicity of administration are important, especially when considering speedy delivery.

Four agents are licensed in the UK: SK (non-proprietary and Streptase), alteplase (Actilyse), reteplase (Rapilysin), and tenecteplase (Metalyse).
Each must be reconstituted before use. SK must be infused over an hour, making it more suitable for hospital than community use. Two drugs are bodyweight dependentMetalyse, which is injected in a single bolus and alteplase, which must be infused, working best with an accelerated infusion rate. Reteplase is independent of weight and is injected as a double bolus, 30 minutes apart.

Only SK does not require heparin as adjunctive therapy for at least 24 hours to prevent re-thrombosis.

\section{TRENDS IN HOSPITAL BASED THROMBOLYSIS THERAPY}

SK the cheapest thrombolytic, has been the UK's drug of choice in a first infarction for many years. For a second infarct, however, most clinicians recommend an alternative agent as antibodies to streptokinase develop in almost half of all patients; these persist for years, rendering further administration of SK useless. European and American doctors favour Alteplase, which produces marginally better outcomes in younger patients and those with an anterior infarct.

With many units adopting protocol driven thrombolysis, the greater convenience, simple dosing regimen, ease, and 
speed of administration and time and cost saving of bolus thrombolytics become more apparent, especially when considering emergency treatment in the community.

\section{THROMBOLYSIS IN THE PREHOSPITAL ENVIRONMENT}

Even modest delays in treatment may be detrimental as myocardial cell death starts within minutes of symptom onset so the finding in the GREAT trial ${ }^{15}$ that prehospital thrombolysis saved lives was not surprising. This ought to become routine clinical practice, with the goal of minimising pain to needle time.

Rural patients with prolonged ambulance transport times are likely to benefit from early thrombolytic treatment in the community but even urban patients should be considered for community thrombolysis if traffic congestion is likely to delay treatment.

\section{KEY FACTORS IN PROVIDING EFFECTIVE PREHOSPITAL THROMBOLYSIS}

Usually drugs are prescribed on an individual basis to an individual patient by a doctor. Legislative changes to allow non-medical health professionals to prescribe drugs may be necessary, including a detailed written instruction relating to the supply and administration of specific drugs in specific clinical settings—a Patient Group Directive.

Training, experience, and confidence are essential key components of any successful clinical intervention. UK paramedics already have a variety of clinical skills relevant to the management of acute coronary disease in the community; inevitably, some will need training in ECG recognition and others in drug administration but all will need to become confident in the decision making process of who should, and should not, be thrombolysed. Pending the provision of a round the clock service of paramedics able to manage infarct patients independently, access to advice from a nearby CCU, or some other remote source will be invaluable. Development of a robust protocol designed in conjunction with and shared by secondary care would be clinically invaluable.

\section{DELIVERING PREHOSPITAL THROMBOLYSIS THROUGHOUT UK}

Community thrombolysis is already available in some parts of the UK. Patient Group Direction, growing awareness of and interest in thrombolysis will facilitate an expansion of the number of crews able to provide prehospital treatment.

\section{PRIMARY ANGIOPLASTY: ALTERNATIVE OR ADJUNCT TO THROMBOLYSIS?}

Percutaneous coronary angioplasty, well established in chronic stable angina, opens the occluded artery mechanically, first restoring coronary patency by disrupting the acute thrombosis with a high degree of certainty (unlike chemical lysis in which reperfusion is assumed if the ST segments of the ECG resolve soon after thrombolysis); and second obliterating the underlying coronary plaque.

Angioplasty may be offered as a primary procedure in preference to thrombolysis or as an adjunct when thrombolysis has failed to restore the ST segments to baseline within 90 minutes, so called rescue angioplasty. Both strategies require an important commitment in terms of laboratory access and trained staff but in-hospital mortality can be as low as $2 \% .^{20}$

A meta-analysis of 23 trials reported that angioplasty may have the edge, reducing re-infarctions, strokes, and mortality over in-hospital lysis ${ }^{21}$ but not prehospital lysis. ${ }^{22}$

\section{A VIEW OF THE FUTURE FOR ACUTE MYOCARDIAL INFARCTION IN THE UK}

Coronary angioplasty has become widely available in many centres in Europe and the USA, either as primary treatment or as rescue for failed reperfusion. Guidelines from the European Society of Cardiology $y^{23}$ now recommend angioplasty rather than thrombolysis, provided that it can be delivered within 90 minutes of first medical contact.

At present, most NHS patients will be given a thrombolytic agent, as few units are able to provide a round the clock angioplasty service. The Hammersmith Hospital, London runs the UK's first round the clock primary angioplasty service and their 30 day mortality is reported as 3\% with angioplasty compared with $12 \%$ for thrombolysis. ${ }^{24}$ Hospitals able to fund a similar service may soon receive patients with an acute infarction diverted from a local hospital to a designated heart attack centre for mechanical clot dissolution rather than chemical lysis.

\section{POTENTIAL IMPLICATIONS FOR THE UK}

Undoubtedly, setting up heart attack centres would demand considerable investment in equipment, training, and staffing levels; existing services would have to be reconfigured; more out of hours work might warrant shift working of key cardiac catheter lab staff; greater journey times from remote country areas would place greater strain on ambulance services already struggling to meet response time targets; delayed treatment because of travelling might precipitate potentially fatal arrrhythmia; and patients and their relatives might be inconvenienced. Routine angiography after thrombolysis has been proposed, ${ }^{25}$ so with lab staff and equipment on continual alert, there may well be an adverse (albeit unintended) impact on elective angiography and angioplasty rates.

The financial, staffing, and training implications are considerable. Commissioning new catheter lab facilities might be prohibitively expensive so it is probable that existing units will face unprecedented and potentially overwhelming demand.

\section{CONCLUSION}

In acute myocardial infarction, medical practice has changed considerably over the past 40 years, rapidly incorporating clinical trial findings into clinical practice.

Time remains an important factor in acute myocardial infarction. Thrombolysis and primary angioplasty can do little to reduce the $50 \%$ of all deaths that occur in the community ${ }^{26}$ unless medical (or paramedical) help is sought more quickly than at present. Campaigns to raise public awareness have met with limited success. ${ }^{27}$ For some patients, their local hospital will provide rapid access to primary angioplasty. For others, the heart attack centre may be relatively remote.

Despite the lack of conclusive data, ${ }^{28}$ thrombolysis given by paramedic crews en route to the heart attack centre may restore coronary patency sufficiently to salvage myocardium. Ambulance crew may observe an increase in cardiac arrhythmia solely because of prolonged contact time. A decision regarding angioplasty can be made on arrival at the centre, either as a rescue procedure or delayed 24 hours.

There are clear differences in cost and cost effectiveness of the various thrombolytics. "Given the similarity in outcome, cost-effectiveness becomes largely determined by the acquisition costs of the drug". ${ }^{29}$ An economic evaluation of the cost effectiveness of primary angioplasty compared with thrombolysis is awaited, but if primary angioplasty emerges as a feasible strategy and displaces thrombolysis as the treatment of choice in acute myocardial infarction in the UK, as it has done in Europe and the USA, clinicians must ensure that it 
does not take the 25 years it took, from first clinical trial reports to routine, optimal provision of lysis on demand, to achieve the same with angioplasty.

\section{REFERENCES}

1 Roberts WC, Buja LM. The frequency and significance of coronary arterial thrombi and observations in fatal acute myocardial infarction: a study of 107 necroscopy patients. Am J Med 1972;52:425-42.

2 Falk E. Plaque rupture with severe pre-existing stenosis precipitating coronary thrombosis: characteristics of coronary atherosclerotic plaques underlying fatal occlusive thrombi. Br Heart J 1983;50:127-34.

3 Davies MJ, Thomas AC. Plaque fissuring: the cause of acute myocardial infarction, sudden death and crescendo angina. Br Heart J 1985;53:363-73.

4 Tillett WS, Garner RL. The fibrinolytic activity of haemolytic streptococci. J Exp Med 1933:58:485-502

5 Rentrop P, Blanke H, Karch KR, et al. Selective intracoronary thrombolysis in acute myocardial infarction and unstable angina pectoris. Circulation $1981 ; 63: 307-17$

6 de Bono D. The European Co-operative Study Group trial of intravenous recombinant tissue-type plasminogen activator (rt-PA) and conservative therapy versus rt-PA and immediate coronary angioplasty. J Am Coll Cardiology 1988; 12(suppl A):20-3A.

7 The ISAM Study Group. A prospective trial of intravenous streptokinase in acute myocardial infarction (ISAM). Mortality, morbidity and infarct size at 21 days. N Engl J Med 1986;314:1465-71.

8 Gruppo Italiano Per Lo Studio Della Streptochinasi Nell' Infarto Miocardio (GISSI). Effectiveness of intravenous thrombolytic treatment in acute myocardial infarction. Lancet 1986;i:397-402.

9 The ISIS-2 Collaborative Study Group. Randomised trial of intravenous streptokinase, oral aspirin, both, or neither among 17187 cases of suspected acute myocardial infarction: ISIS-2. Lancet 1988;ii:349-60.

10 The AIMS group. Effect of intravenous APSAC on mortality after acute myocardial infarction: preliminary report of a placebo-controlled clinical trial. Lancet 1988;i:545-9.

11 The GUSTO Investigators. An international randomized trial comparing four thrombolytic strategies for acute myocardial infarction. N EnglJ Med 1993;329:673-82

12 Cannon CP, McCabe CH, Diver DJ, et al. Comparison of front-loaded recombinant tissue-type plasminogen activator, anistreplase and combination thrombolytic therapy for acute myocardial infarction: results of the thrombolysis in myocardial infarction (TIMI) 4 trial. J Am Coll Cardiol 1994;24:1602-10

13 Anon. Randomised, double blind comparison of reteplase double bolus administration with streptokinase in acute myocardial infarction (INJECT): trial to investigate equivalence. Lancet 1995;346:329-36.

14 Assessment of the Safety and Efficacy of a New Thrombolytic (ASSENT-2) Investigators. Single-bolus tenecteplase compared with front-loaded alteplase in acute myocardial infarction: the ASSENT-2 double-blind randomised trial Lancet 1999;354:726-22.

15 Rawles J. Quantification of the benefit of earlier thrombolytic therapy: fiveyear results of the Grampian Region early anistreplase trial (GREAT). J Am Coll Cardiol 1997; 30:1181-6.

16 Fibrinolytic Therapy Trialists' (FTT) Collaborative Group. Indications for fibrinolytic therapy in suspected acute myocardial infarction: collaborative overview of early mortality and major morbidity results from all randomised trials of more than 1000 patients. Lancet 1994;343:31 1-22.

17 Boersma E, Maas AC, Deckers JW, et al. Early thrombolytic treatment in acute myocardial infarction: reappraisal of the golden hour. Lancet 1996:348:771-5.

18 The National Service Framework for Coronary Heart Disease. http:// www.doh.gov.uk/nsf/coronary.htm.

19 Myocardial Infarction National Audit Project. http://www.rcplondon.ac.uk/ college/ceeu/ceeu ami home.htm.

20 Grines CL, Cox DA, Stone GW, et al, for The Stent Primary Angioplasty in Myocardial Infarction Study Group. Coronary angioplasty with or without stent implantation for acute myocardial infarction. N Engl J Med 1999;341:1949-56

21 Keeley EC, Boura JA, Grines CL. Primary angioplasty versus intravenous thrombolytic therapy for acute myocardial infarction: a quantitative review of 23 randomised trials. Lancet 2003;361:13-20.

22 Widimsky $\mathbf{P}$, Budesinsky T, Vorac D, et al. Long distance transport for primary angioplasty vs immediate thrombolysis in acute myocardial infarction. Final results of the randomised national multi-centre trial- PRAGUE-2. Eur Heart $J$ 2003;24:94-104.

23 Task Force on the Management of Acute Myocardial Infarction of the European Society of Cardiology. Management of acute myocardial infarction presenting with ST-segment elevation. Eur Heart J 2003;24:28-66.

24 Hammersmith Hospital pioneers new treatment for heart attacks. http:// www.hhnt.org/news/paces.htm.

25 Fernandez-Aviles F, Alonso JJ, Castro-Beiras A, et al. Routine invasive strategy within 24 hours of thrombolysis versus ischaemia-guided conservative approach for acute myocardial infarction with ST-segment elevation (GRACIA-1): a randomised controlled trial. Lancet 2004;364:1045-53.

26 American Heart Association statistics. http://www.americanheart.org.

27 Herlitz J, Hartford M, Blohm M, et al. Effects of a media campaign on delay time and ambulance use in suspected acute myocardial infarction. Am J Cardiol 1989;64:90-3.

28 Steg PG, Bonnefoy E, Chabaud S, et al. Impact of time to treatment on mortality after pre-hospital fibrinolysis or primary angioplasty: data from the CAPTIM randomized clinical trial. Circulation 2003;108:2851-6.

29 Boland A, Dundar Y, Bagust A, et al. Early thrombolysis for the treatment of acute myocardial infarction: a systematic review and economic evaluation. Health Technology Assessment NHS R\&D HTA Programme 2003. http:// wwwncchta.org.

bmjupdates+

bmjupdates+ is a unique and free alerting service, designed to keep you up to date with the medical literature that is truly important to your practice.

bmjupdates+ will alert you to important new research and will provide you with the best new evidence concerning important advances in health care, tailored to your medical interests and time demands.

Where does the information come from?

bmiupdates+ applies an expert critical appraisal filter to over 100 top medical journals A panel of over 2000 physicians find the few 'must read' studies for each area of clinical interest

Sign up to receive your tailored email alerts, searching access and more...

www.bmjupdates.com 